\title{
Synthesis and Characterization of Ferrocene Derivatives and Preliminarily Electrocatalytic Oxidation of L-Cysteine at Nafion-Ferrocene Derivatives Modified Glassy Carbon Electrode
}

\author{
Jianping Yong, ${ }^{1}$ Xiaoyu Jiang, ${ }^{2}$ Xiaoyuan Wu, ${ }^{1}$ Shuijin Huang, \\ Qikai Zhang, ${ }^{1}$ and Canzhong $\mathrm{Lu}^{1}$ \\ ${ }^{1}$ State Key Laboratory of Structural Chemistry, Fujian Institute of Research on the Structure of Matter, \\ Chinese Academy of Sciences, Fuzhou 350002, China \\ ${ }^{2}$ Fujian University of Technology, Fuzhou 350108, China \\ Correspondence should be addressed to Canzhong Lu; czlu@fjirsm.ac.cn
}

Received 2 April 2014; Revised 23 April 2014; Accepted 7 May 2014; Published 25 May 2014

Academic Editor: Fazlul Haq

Copyright (c) 2014 Jianping Yong et al. This is an open access article distributed under the Creative Commons Attribution License, which permits unrestricted use, distribution, and reproduction in any medium, provided the original work is properly cited.

Five new structural ferrocene derivatives (2a 2e) were firstly synthesized and characterized by ${ }^{1} \mathrm{H} N M R,{ }^{13} \mathrm{C}$ NMR, ESI-MS, and XRD. Subsequently, the preliminarily electrocatalytic oxidation of L-cysteine (L-Cys) at nafion-ferrocene derivatives modified glassy carbon electrode (GCE) has also been investigated by cyclic voltammetry. The results showed that $2 \mathrm{e}$ can dramatically electrocatalyze the oxidation of L-cysteine at its modified GCE in $0.1 \mathrm{~mol} \mathrm{~L}^{-1} \mathrm{NaNO}_{3}$ aqueous solution with a quasireversible process with $\Delta E_{p} \approx 55 \mathrm{mV}$.

\section{Introduction}

Ferrocene derivatives have attracted considerable attention for their potential applications as nonlinear optical devices, functional materials in electrochemical sensor [1-4], and chiral catalysts [5-7]. In addition, ferrocene derivatives have also attracted wide interest for their considerably biological activities [8-15]. For example, the ferroquine (FQ, SSR97193, Figure 1) is about to complete phase II clinical trials as a treatment for uncomplicated malaria [16].

L-Cysteine (L-Cys) plays a crucial role in both bioand environmental chemistry and can be applied in many biochemical processes and diagnosis of disease states. Especially, L-Cys provides a modality for the intramolecular crosslinking of proteins through disulfide bonds to support their secondary structures and functions. Therefore, it is very important to develop simple and effective methods to trace LCys detection. Many methods, such as spectrometric method [17], chromatography [18], and electrochemical method [1923], have been used to detect the trace content of L-Cys.
However, electrochemical method has attracted considerable attention for simple operation, fast response, and sensitive in situ detection.

The oxidation of L-Cys at $\mathrm{Hg}, \mathrm{Au}, \mathrm{Ag}, \mathrm{Pt}$, and diamond electrodes has been reported [24-27]. However, the direct oxidation of L-Cys at GCE is very sluggish. Ferrocene derivatives have been used as the selective probes for detecting the trace ions, biomacromolecules [28-32]. Nafion is a special material, which possesses widespread applications in the field of electrochemistry analysis, chemical sensor, and nanomaterials [33, 34]. According to our survey, no electrocatalytic oxidation of L-Cys at the nafionferrocene derivatives modified GCE has been reported. In this work, five new structural ferrocene derivatives (2a 2e) (Scheme 1) were firstly synthesized and then confirmed by IR, ${ }^{1} \mathrm{H}$ NMR, ${ }^{13} \mathrm{C}$ NMR, MS, and XRD. Subsequently, their preliminarily electrocatalytic oxidation of L-Cys at the nafion-ferrocene derivatives modified GCE has also been investigated. 


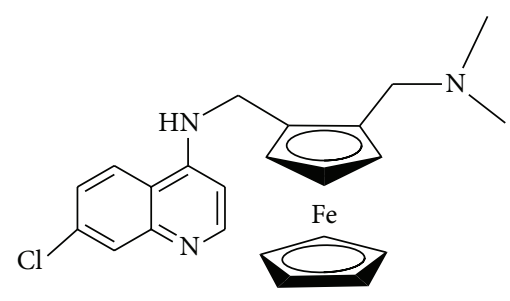

Figure 1
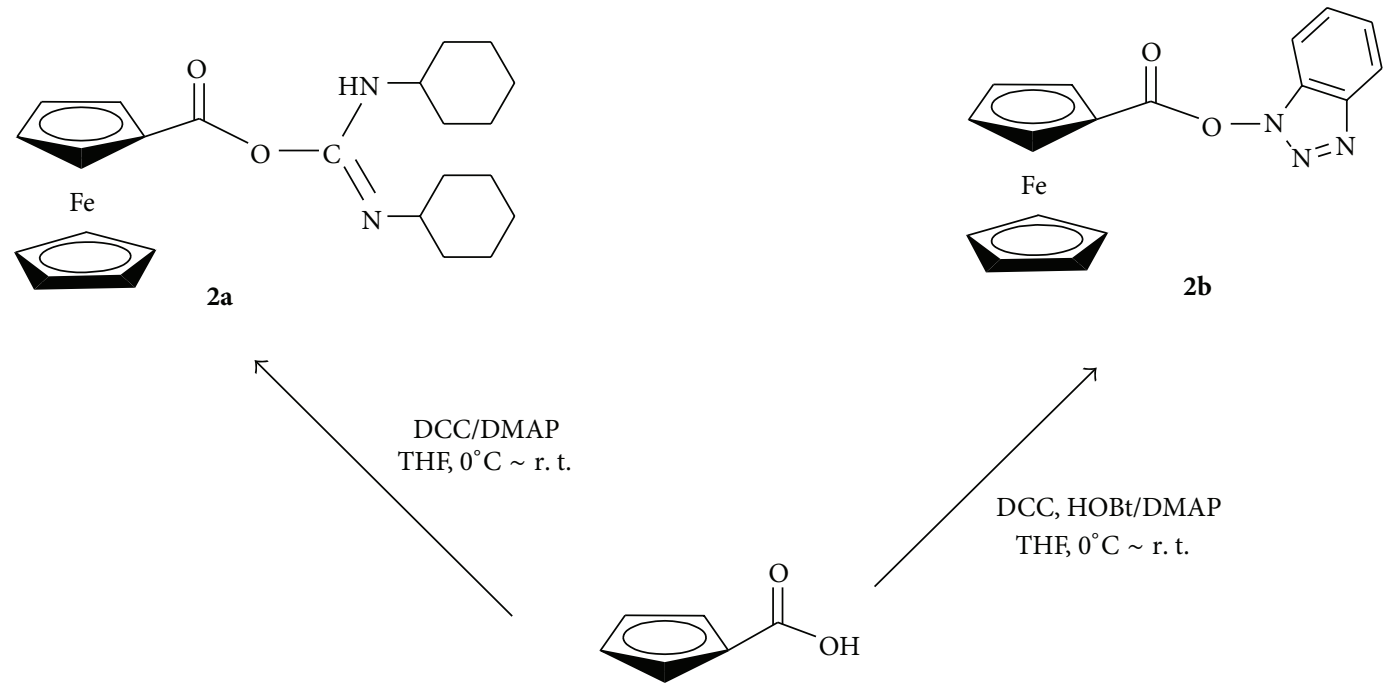

$\mathrm{Fe}$

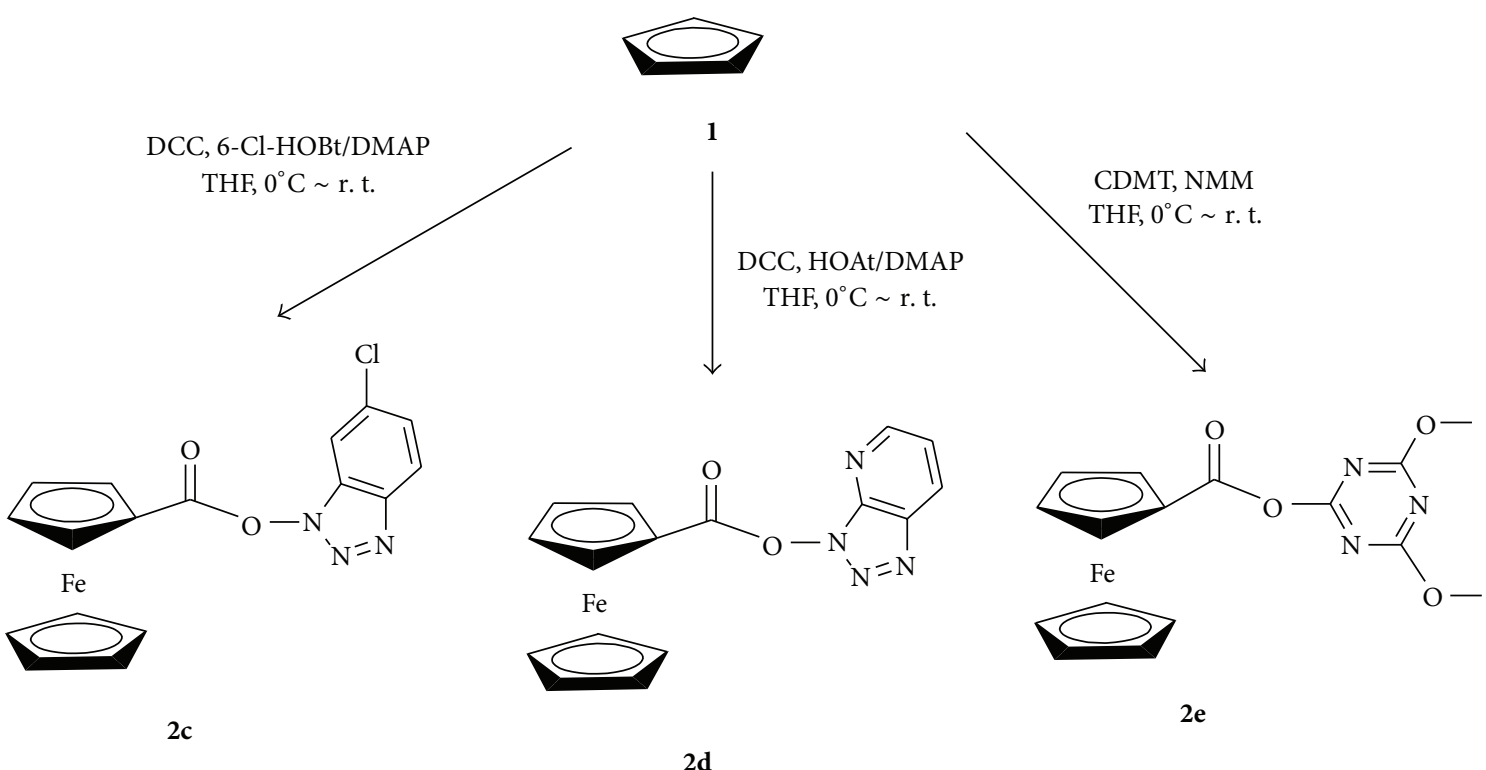

Scheme 1: Synthetic routes of ferrocene derivatives.

\section{Experimental Details}

2.1. Materials and Apparatus. 2-Chloro-4,6-dimethoxy$[1,3,5]$ triazine (CDMT), N,N'-dicyclohexylcarbodiimide (DCC), 1-hydroxybenzotriazole (HOBt), 6-Chloro-1-hydroxybenzotriazole (6-Cl-HOBt), 1-hydroxyl-7-azabenzotriazole
(HOAt), 4-dimethylaminopyridine (DMAP), and $\mathrm{N}$ methylmorpholine (NMM) were purchased from Aladdin Reagent company. $5 \mathrm{wt} \%$ Nafion solution (DuPont, USA) and other chemicals were commercially available and used without further purification. All melting points were determined on X-4 micro-melting points apparatus and 
values are uncorrected. ${ }^{1} \mathrm{H}(400 \mathrm{MHz})$ and ${ }^{13} \mathrm{C}$ NMR $(100 \mathrm{MHz})$ spectra were recorded on a $400 \mathrm{MHz}$ Bruker AVANCE III spectrometer in $\mathrm{CDCl}_{3}$. The chemical shifts are expressed in ppm relative to tetramethylsilant (TMS) as the internal standard; ESI-MS was performed on a DECAX30000 LCQ Deca XP (70 Ev). FTIR spectra were recorded on Spectrum One with $\mathrm{KBr}$ disks in the $600-3600 \mathrm{~cm}^{-1}$ region. All electrochemical experiments were carried out using an electrochemistry workstation CHI760 (CH Instrument Inc., USA). The working electrode used in cyclic voltammetry experiments was a CHI104 glassy carbon electrode with a geometric area of ca. $0.15 \mathrm{~cm}^{2}$; a twisted platinum wire auxiliary electrode and $\mathrm{Ag} / \mathrm{AgCl}$ served as the reference electrode. Tetrahydrofuran (THF) was distilled over sodium and benzophenone before being used; all electrolyte solutions were prepared with doubly distilled water.

\subsection{Synthesis Parts}

2.2.1. Synthesis of 2-Ferrocene Carboxylic Acid-1,3dicyclohexyl-isourea (2a) [35]. Ferrocene carboxylic acid 1 $(0.46 \mathrm{~g}, 2 \mathrm{mmol})$ and DCC $(0.453 \mathrm{~g}, 2.2 \mathrm{mmol})$ were added into a $100 \mathrm{~mL}$ one necked round bottom flask with $20 \mathrm{~mL}$ dry THF. This mixture was stirred under cold bath and a THF solution $(10 \mathrm{~mL})$ containing DMAP $(0.268 \mathrm{~g}, 2.2 \mathrm{mmol})$ was added dropwise by syringe, the mixture was stirred under cold bath for $30 \mathrm{~min}$, and then temperature rose naturally to room temperature. The completion of reaction was judged from the simple TLC analysis. The mixture was evaporated under reduced pressure and the residual directly purified by column chromatography (EtOAc/petroleum ether: 5:1 to $2: 1)$ to give the desired compound $2 \mathrm{a}$.

Light yellow solid $(0.75 \mathrm{~g}, 86 \%$ yield $)$. M.p. $173^{\circ} \mathrm{C}$, IR $\left(\mathrm{cm}^{-1}\right): 3235(\mathrm{NH}), 3039(=\mathrm{C}-\mathrm{H}), 2931(\mathrm{C}-\mathrm{H}), 1701(\mathrm{O}=\mathrm{C}-$ O- $), 1598(\mathrm{C}=\mathrm{C}), 1542(\mathrm{C}=\mathrm{N}), 1182(\mathrm{C}-\mathrm{O}) ;{ }^{1} \mathrm{H}$ NMR $\left(\mathrm{CDCl}_{3}\right)$ $\delta=0.92-1.33(\mathrm{~m}, 8 \mathrm{H}), 1.35-1.66(\mathrm{~m}, 5 \mathrm{H}), 1.79-1.85(\mathrm{~m}, 6 \mathrm{H})$, $1.99-2.09(\mathrm{~m}, 2 \mathrm{H}), 3.48-3.53(\mathrm{~m}, 1 \mathrm{H}), 4.19\left(\mathrm{~s}, 5 \mathrm{H}, \mathrm{C}_{5} \mathrm{H}_{5}\right), 4.28$ $\left(\mathrm{t}, J=2.0 \mathrm{~Hz}, 2 \mathrm{H}\right.$ of $\left.\mathrm{C}_{5} \mathrm{H}_{4}\right), 4.67\left(\mathrm{t}, J=1.6 \mathrm{~Hz}, 2 \mathrm{H}\right.$ of $\left.\mathrm{C}_{5} \mathrm{H}_{4}\right)$, $6.04(\mathrm{~d}, J=6.4 \mathrm{~Hz}, 1 \mathrm{H}, \mathrm{O}=\mathrm{C}-\mathrm{NH}) ;{ }^{13} \mathrm{C}$ NMR $\left(\mathrm{CDCl}_{3}\right) \delta=$ 24.6, 25.4, 25.5, 26.3, 30.9, 31.1, 31.2, 31.3, 32.6, 47.7, 49.8, 56.8, 70.4, $77.9\left(\mathrm{C}_{5} \mathrm{H}_{4}\right), 70.3\left(\mathrm{C}_{5} \mathrm{H}_{5}\right), 154.9(\mathrm{C}=\mathrm{N}), 171.9(-\mathrm{C}=\mathrm{O})$; MS (ESI): $m / z 436[\mathrm{M}]^{+}$.

2.2.2. Synthesis of Ferrocene Carboxylic Acid Benzotriazol-1$y$ l Ester (2b). Ferrocene carboxylic acid $\mathbf{1}(0.46 \mathrm{~g}, 2 \mathrm{mmol})$, DCC (0.453 g, $2.2 \mathrm{mmol})$, and HOBt (0.337 g, $2.5 \mathrm{mmol}$ ) were added into a $100 \mathrm{~mL}$ one necked round bottom flask with $20 \mathrm{~mL}$ dry THF. This mixture was stirred under cold bath and a THF solution $(10 \mathrm{~mL})$ containing DMAP $(0.268 \mathrm{~g}$, $2.2 \mathrm{mmol}$ ) was added dropwise by syringe, the mixture was stirred under cold bath for $30 \mathrm{~min}$, and then temperature rose naturally to room temperature. The completion of reaction was judged from the simple TLC analysis. The mixture was evaporated under reduced pressure and the residual purified directly by column chromatography (EtOAc/petroleum ether: $5: 1$ to $2: 1$ ) to give the desired compound $\mathbf{2 b}$.

Light yellow solid (0.638 g, 92\% yield). M.p. $141-142^{\circ} \mathrm{C}$, IR $\left(\mathrm{cm}^{-1}\right)$ : 3035 (=C-H), $1776(\mathrm{O}=\mathrm{C}-\mathrm{O}-), 1441(\mathrm{C}=\mathrm{C}), 1261$
$(\mathrm{C}=\mathrm{N}), 1054(\mathrm{C}-\mathrm{O}), 768(\mathrm{Ph}) ;{ }^{1} \mathrm{H}$ NMR $\left(\mathrm{CDCl}_{3}\right) \delta=4.42$ $\left(\mathrm{s}, 5 \mathrm{H}, \mathrm{C}_{5} \mathrm{H}_{5}\right), 4.67\left(\mathrm{t}, J=2.0 \mathrm{~Hz}, 2 \mathrm{H}\right.$ of $\left.\mathrm{C}_{5} \mathrm{H}_{4}\right), 5.07(\mathrm{t}, J=$ $1.0 \mathrm{~Hz}, 2 \mathrm{H}$ of $\left.\mathrm{C}_{5} \mathrm{H}_{4}\right), 7.39-7.45(\mathrm{~m}, 2 \mathrm{H}), 7.52(\mathrm{~d}, J=7.2 \mathrm{~Hz}$, $1 \mathrm{H}), 8.08(\mathrm{~d}, J=8.4 \mathrm{~Hz}, 1 \mathrm{H}) ;{ }^{13} \mathrm{C} \mathrm{NMR}\left(\mathrm{CDCl}_{3}\right) \delta=63.7$, 70.8, $73.5\left(\mathrm{C}_{5} \mathrm{H}_{4}\right), 71.0\left(\mathrm{C}_{5} \mathrm{H}_{5}\right), 108.4,120.5,124.7,128.6,128.9$, 143.6 (benzotriazol-ring), $168.3(-\mathrm{O}-\mathrm{C}=\mathrm{O})$; $\mathrm{MS}(\mathrm{ESI}): \mathrm{m} / \mathrm{z}$ $347[\mathrm{M}]^{+}$.

2.2.3. Synthesis of Ferrocene Carboxylic Acid 6-Chlorobenzotriazol-1-yl Ester (2c). The detailed process for synthesis of $\mathbf{2} \mathbf{c}$ is the same as of $\mathbf{2 b}$. Red crystal ( $0.723 \mathrm{~g}, 75 \%$ yield). M.p. $112-113^{\circ} \mathrm{C}$, IR $\left(\mathrm{cm}^{-1}\right)$ : $3100(=\mathrm{C}-\mathrm{H}), 1792(\mathrm{O}=\mathrm{C}-\mathrm{O}-)$, $1445(\mathrm{C}=\mathrm{C}), 1286(\mathrm{C}=\mathrm{N}), 1029(\mathrm{C}-\mathrm{O}), 881(\mathrm{C}-\mathrm{Cl}), 827(\mathrm{Ph})$; ${ }^{1} \mathrm{H} \mathrm{NMR}\left(\mathrm{CDCl}_{3}\right) \delta=4.47\left(\mathrm{~s}, 5 \mathrm{H}, \mathrm{C}_{5} \mathrm{H}_{5}\right), 4.72(\mathrm{t}, J=2.1 \mathrm{~Hz}$, $2 \mathrm{H}$ of $\left.\mathrm{C}_{5} \mathrm{H}_{4}\right), 5.10\left(\mathrm{t}, J=1.3 \mathrm{~Hz}, 2 \mathrm{H}\right.$ of $\left.\mathrm{C}_{5} \mathrm{H}_{4}\right), 7.41(\mathrm{dd}, J=1.6$, $1.6 \mathrm{~Hz}, 1 \mathrm{H}), 7.49(\mathrm{~d}, J=1.6 \mathrm{~Hz}, 1 \mathrm{H}), 8.03(\mathrm{~d}, J=8.8 \mathrm{~Hz}, 1 \mathrm{H})$; ${ }^{13} \mathrm{C} \mathrm{NMR}\left(\mathrm{CDCl}_{3}\right) \delta=63.7,71.3,73.9\left(\mathrm{C}_{5} \mathrm{H}_{4}\right), 71.4\left(\mathrm{C}_{5} \mathrm{H}_{5}\right)$, 108.6, 121.8, 126.4, 129.9, 135.5, 142.4 (benzotriazol-ring), 168.5; MS (ESI): $m / z 482[\mathrm{M}]^{+}$.

2.2.4. Synthesis Ferrocene Carboxylic Acid [1,2,3]triazolo[4,5b]pyridin-3-yl Ester (2d). The detailed process for synthesis of $\mathbf{2 d}$ is the same as synthesis of $\mathbf{2 b}$. Light yellow solid $(0.557$ g, $80 \%$ yield $)$. M.p. $136-137^{\circ} \mathrm{C}, \mathrm{IR}\left(\mathrm{cm}^{-1}\right): 3108(=\mathrm{C}-\mathrm{H})$, $1775(\mathrm{O}=\mathrm{C}-\mathrm{O}), 1448(\mathrm{C}=\mathrm{C}), 1265(\mathrm{C}=\mathrm{N}), 1058(\mathrm{C}-\mathrm{O}), 887$; ${ }^{1} \mathrm{H}$ NMR $\left(400 \mathrm{MHz}, \mathrm{CDCl}_{3}\right) \delta=4.44\left(\mathrm{~s}, 5 \mathrm{H}, \mathrm{C}_{5} \mathrm{H}_{5}\right), 4.61(\mathrm{~s}$, $2 \mathrm{H}$ of $\left.\mathrm{C}_{5} \mathrm{H}_{4}\right), 5.03\left(\mathrm{~s}, 2 \mathrm{H}\right.$ of $\left.\mathrm{C}_{5} \mathrm{H}_{4}\right), 7.38(\mathrm{dd}, J=4.8,4.8 \mathrm{~Hz}$, $1 \mathrm{H}), 8.38(\mathrm{~d}, J=8.4 \mathrm{~Hz}, 1 \mathrm{H}), 8.68(\mathrm{~d}, J=4.4 \mathrm{~Hz}, 1 \mathrm{H}) ;{ }^{13} \mathrm{C}$ $\operatorname{NMR}\left(\mathrm{CDCl}_{3}\right) \delta=63.5,71.1,73.5\left(\mathrm{C}_{5} \mathrm{H}_{4}\right), 71.3\left(\mathrm{C}_{5} \mathrm{H}_{5}\right), 129.5$, 135.1, 140.9, 151.7 ([1,2,3]triazolo[4,5-b]pyridin-ring), 168.1 ($\mathrm{O}-\mathrm{C}=\mathrm{O}) ; \mathrm{MS}(\mathrm{ESI}): m / z 348[\mathrm{M}]^{+}$.

2.2.5. Synthesis of Ferrocene Carboxylic Acid 4,6-Dimethoxy[1,3,5]triazin-2-yl Ester (2e). Ferrocene carboxylic acid 1 $(0.46 \mathrm{~g}, 2 \mathrm{mmol})$ and CDMT $(0.438 \mathrm{~g}, 2.5 \mathrm{mmol})$ were added into a $100 \mathrm{~mL}$ one necked round bottom flask with $20 \mathrm{~mL}$ dry THF. This mixture was stirred under cold bath and a THF solution $(10 \mathrm{~mL})$ containing NMM $(0.253 \mathrm{~g}, 2.5 \mathrm{mmol})$ was added dropwise by syringe, the mixture was stirred under cold bath for $30 \mathrm{~min}$, and then temperature rose naturally to room temperature. The completion of reaction was judged from the simple TLC analysis. The mixture was evaporated under reduced pressure and the residual purified directly by column chromatography (EtOAc/etroleum ether: $5: 1$ to $2: 1$ ) to give the desired compound $2 \mathrm{e}$.

Light yellow solid $\left(0.863 \mathrm{~g}, 92 \%\right.$ yield). M.p. $90-92^{\circ} \mathrm{C}$, FTIR $\left(\mathrm{cm}^{-1}\right): 3104(=\mathrm{C}-\mathrm{H}), 2951(\mathrm{C}-\mathrm{H}), 1747(\mathrm{O}=\mathrm{C}-\mathrm{O})$, $1577(\mathrm{C}=\mathrm{C}), 1469(\mathrm{C}=\mathrm{N}), 1366(\mathrm{C}-\mathrm{O}) ;{ }^{1} \mathrm{H}$ NMR $(400 \mathrm{MHz}$, $\left.\mathrm{CDCl}_{3}\right) \delta(\mathrm{ppm}): 4.08\left(\mathrm{~s}, 6 \mathrm{H}, 2 \mathrm{OCH}_{3}\right), 4.39\left(\mathrm{~s}, 5 \mathrm{H}, \mathrm{C}_{5} \mathrm{H}_{4}\right)$, $4.56\left(\mathrm{~s}, 2 \mathrm{H}\right.$ of $\left.\mathrm{C}_{5} \mathrm{H}_{4}\right), 4.95\left(\mathrm{~s}, 2 \mathrm{H}\right.$ of $\left.\mathrm{C}_{5} \mathrm{H}_{4}\right) ;{ }^{13} \mathrm{C}$ NMR $\left(\mathrm{CDCl}_{3}\right)$ $\delta=56.4\left(\mathrm{OCH}_{3}\right), 70.6,71.3,73.1\left(\mathrm{C}_{5} \mathrm{H}_{4}\right), 71.4\left(\mathrm{C}_{5} \mathrm{H}_{5}\right)$, $167.9(-\mathrm{C}=\mathrm{O}), 171.2,174.5([1,3,5]$ triazin-ring); $\mathrm{MS}(\mathrm{ESI}): \mathrm{m} / z$ $369[\mathrm{M}]^{+}$.

\subsection{Electrochemistry}

2.3.1. The Process for Preparation of the Solutions of NafionFerrocene Derivatives. Compound 2a $(6.6 \mathrm{mg}, 0.015 \mathrm{mmol})$ 


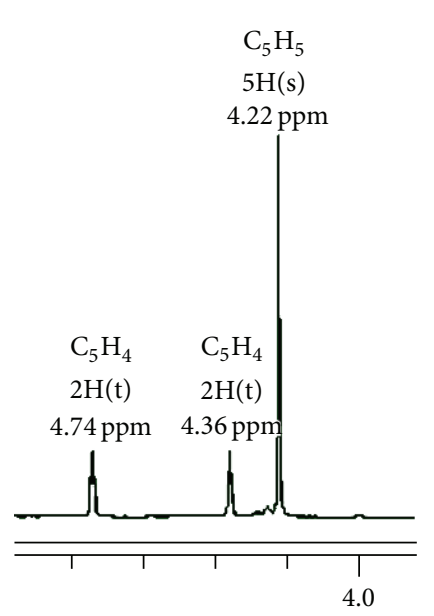

$2 \mathbf{a}$

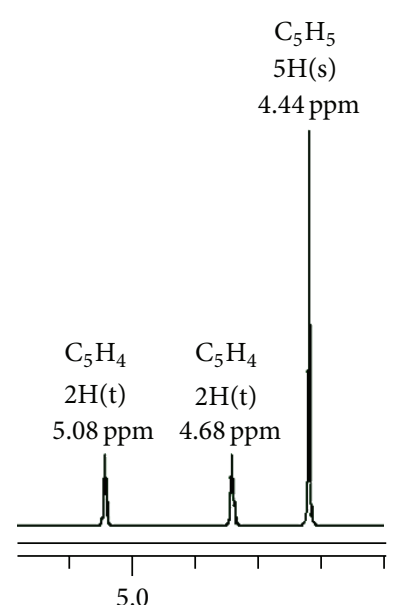

$2 \mathrm{~b}$

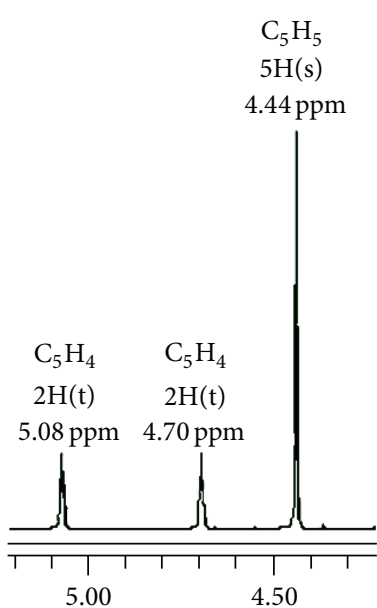

2c

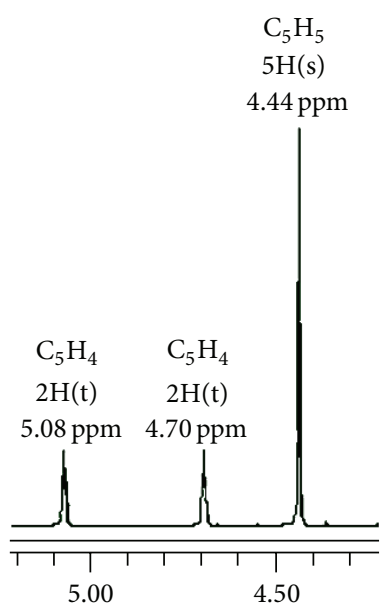

$2 d$

Figure 2: Characteristic fragments of ${ }^{1} \mathrm{H}$ spectra of ferrocene ring in ferrocene derivatives $\mathbf{2 a} \sim \mathbf{2 d}$.

and $50 \mu \mathrm{L} 5 \%$ nafion solution were added in a $2 \mathrm{~mL}$ centrifugal tube, then $1 \mathrm{~mL}$ of absolute alcohol was added, and the mixture was sonicated for $10 \mathrm{~min}$ to obtain the solution of $1.5 \times 10^{-2} \mathrm{~mol} \mathrm{~L}^{-1} \mathbf{2 a}$.

The detailed process for preparing the solutions of 1.5 $\times 10^{-2} \mathrm{~mol} \mathrm{~L}^{-1} \mathbf{2 b}, \mathbf{2 c}, \mathbf{2 d}$, and $\mathbf{2 e}$ is the same as $\mathbf{2 a}$.

2.3.2. General Process for Preparing the Modified Glassy Carbon Electrode and Preliminarily Electrocatalytic Oxidation of L-Cysteine. A GCE was polished with $0.1 \mu \mathrm{m} \alpha-\mathrm{Al}_{2} \mathrm{O}_{3}$, rinsed with doubly distilled water, sonicated in $1 \mathrm{~mol} \mathrm{~L}^{-1}$ $\mathrm{H}_{2} \mathrm{SO}_{4}$ for $5 \mathrm{~min}$, and rinsed with doubly distilled water again prior to each experiment. Then, it was dried naturally.

A modified GCE was prepared by placing $5 \mu \mathrm{L}$ of solution prepared in Section 2.3.1 onto the dried GCE surface by microsyringe. The electrode was dried naturally to obtain the modified GCE.

The modified GCE, a twisted platinum wire electrode, and $\mathrm{Ag} / \mathrm{AgCl}$ electrode were dipped into $20 \mathrm{~mL}(\mathrm{~V} / \mathrm{V}, 1: 1)$ water solution of $6.0 \times 10^{-3} \mathrm{~mol} \mathrm{~L}^{-1} \mathrm{~L}-\mathrm{Cys}$ and $0.1 \mathrm{~mol} \mathrm{~L}^{-1}$ $\mathrm{NaNO}_{3}$. The $\mathrm{Ag} / \mathrm{AgCl}$ electrode was connected to the main body of the cell through a luggin capillary whose end was connected on the modified GCE and positioned close to the electrode surface. The solution was thoroughly flushed with high purity nitrogen for $5 \mathrm{~min}$ before each run to remove the oxygen from the solution in the electrochemical cell. All experiments were carried out at room temperature.

\section{Results and Discussion}

3.1. Chemistry. Ferrocene derivatives (2a $\sim 2 \mathbf{e})$ were firstly synthesized in higher yield and their structures were confirmed by IR, ${ }^{1} \mathrm{H}$ and ${ }^{13} \mathrm{C}$ NMR, and mass spectrometry.

There showed three kinds of proton signals for ferrocene core of the ferrocene derivatives (2a $\sim 2 \mathbf{e})$ in ${ }^{1} \mathrm{H}$ NMR spectra (Figure 2), the protons of $\mathrm{C}_{5} \mathrm{H}_{5}$ showed a singlet, the $\mathrm{C}_{5} \mathrm{H}_{4}$ showed two triplets of $\mathbf{2 a} \sim \mathbf{2 c}$, but the $\mathrm{C}_{5} \mathrm{H}_{4}$ showed two
TABLE 1: Crystallographic data and structure refinement for $\mathbf{2 c}$.

\begin{tabular}{lc}
\hline Crystal Data & $2 \mathrm{c}$ \\
Experical formula & $\mathrm{C}_{17} \mathrm{H}_{12} \mathrm{ClFeN}_{3} \mathrm{O}_{2}$ \\
$\mathrm{MW}$ & 381.60 \\
Crystal system & monoclinic \\
Space group & $\mathrm{P} 2(1) / \mathrm{c}$ \\
$a(\AA)$ & $9.6361(8)$ \\
$b(\AA \AA)$ & $13.7876(7)$ \\
$c(\AA)$ & $13.1082(8)$ \\
$\alpha\left(^{\circ}\right)$ & 90.00 \\
$\beta\left(^{\circ}\right)$ & $108.881(8)$ \\
$\gamma\left({ }^{\circ}\right)$ & 90.00 \\
$V\left(\AA^{3}\right)$ & $1647.83(19)$ \\
$Z$ & 4 \\
$D_{c}\left(\mathrm{~g} \mathrm{~cm}^{-1}\right)$ & 1.538 \\
$\mu\left(\mathrm{mm}^{-1}\right)$ & 8.958 \\
$F(000)$ & 776 \\
$\theta$ range $\left(^{\circ}\right)$ & 4.80 to 74.56 \\
Reflections collected/unique & $6006 / 3248$ \\
$R_{\text {int }}$ & 0.0230 \\
$R_{1}, w R_{2}(I>2 \sigma(I))$ & $R_{1}=0.0361, w R_{2}=0.0911$ \\
$R_{1}, w R_{2}($ all data) & $0.0566, w R_{2}=0.1027$ \\
$\mathrm{GOF}^{\circ} F^{2}$ & 0.999 \\
\hline
\end{tabular}

singlets of $2 d$. Three signals of the carbon atoms of $\mathrm{C}_{5} \mathrm{H}_{4}$ and one signal of carbon atom of $\mathrm{C}_{5} \mathrm{H}_{5}$ appear in ${ }^{13} \mathrm{C}$ NMR spectra, while two carbon signals of $\mathrm{C}_{5} \mathrm{H}_{4}$ appear upfield and one carbon signal of $\mathrm{C}_{5} \mathrm{H}_{4}$ appears downfield compared to the carbon signals of $\mathrm{C}_{5} \mathrm{H}_{5}$.

3.2. X-Ray Crystallographic Study. X-ray diffraction data for 2c was collected on a Siemens Smart CCD diffractometer equipped with a graphite-monochromated $\mathrm{CuKa}$ radiation $(\lambda$ $=1.54180$ Á). The structure was solved by direct method using the program SHELXL-97 and refined by full-matrix leastsquares techniques on $F^{2}$ with SHELXL-97 program package $[36,37]$. The molecular structure (Figure 3 ) and crystal data of $2 \mathrm{c}$ are listed in Tables 1 and 2. 


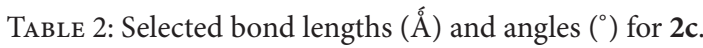

\begin{tabular}{|c|c|c|c|}
\hline \multicolumn{2}{|c|}{ Bond lengths (§́) } & \multicolumn{2}{|c|}{ Bond angle $\left({ }^{\circ}\right)$} \\
\hline $\mathrm{Fe}(1)-\mathrm{C}(9)$ & $2.007(3)$ & $\mathrm{C}(9)-\mathrm{Fe}(1)-\mathrm{C}(8)$ & $41.50(12)$ \\
\hline $\mathrm{Fe}(1)-\mathrm{C}(1)$ & $2.025(3)$ & $\mathrm{C}(9)-\mathrm{Fe}(1)-\mathrm{C}(2)$ & $153.96(14)$ \\
\hline$C(9)-C(11)$ & $1.445(4)$ & $\mathrm{C}(9)-\mathrm{Fe}(1)-\mathrm{C}(5)$ & 127.51(17) \\
\hline $\mathrm{C}(11)-\mathrm{O}(12)$ & $1.185(4)$ & $\mathrm{C}(8)-\mathrm{Fe}(1)-\mathrm{C}(10)$ & $69.73(14)$ \\
\hline $\mathrm{O}(13)-\mathrm{N}(14)$ & $1.362(3)$ & $\mathrm{O}(12)-\mathrm{C}(11)-\mathrm{C}(9)$ & $130.8(3)$ \\
\hline $\mathrm{N}(14)-\mathrm{C}(22)$ & $1.361(3)$ & $\mathrm{O}(13)-\mathrm{N}(14)-\mathrm{N}(15)$ & $118.6(3)$ \\
\hline $\mathrm{C}(20)-\mathrm{Cl}(23)$ & $1.730(3)$ & $\mathrm{N}(16)-\mathrm{C}(17)-\mathrm{C}(22)$ & 109.1(3) \\
\hline $\mathrm{N}(15)-\mathrm{N}(16)$ & $1.295(4)$ & $\mathrm{N}(14)-\mathrm{C}(22)-\mathrm{C}(21)$ & $133.8(2)$ \\
\hline $\mathrm{C}(19)-\mathrm{C}(20)$ & $1.408(4)$ & $\mathrm{C}(19)-\mathrm{C}(20)-\mathrm{Cl}(23)$ & $117.6(2)$ \\
\hline
\end{tabular}

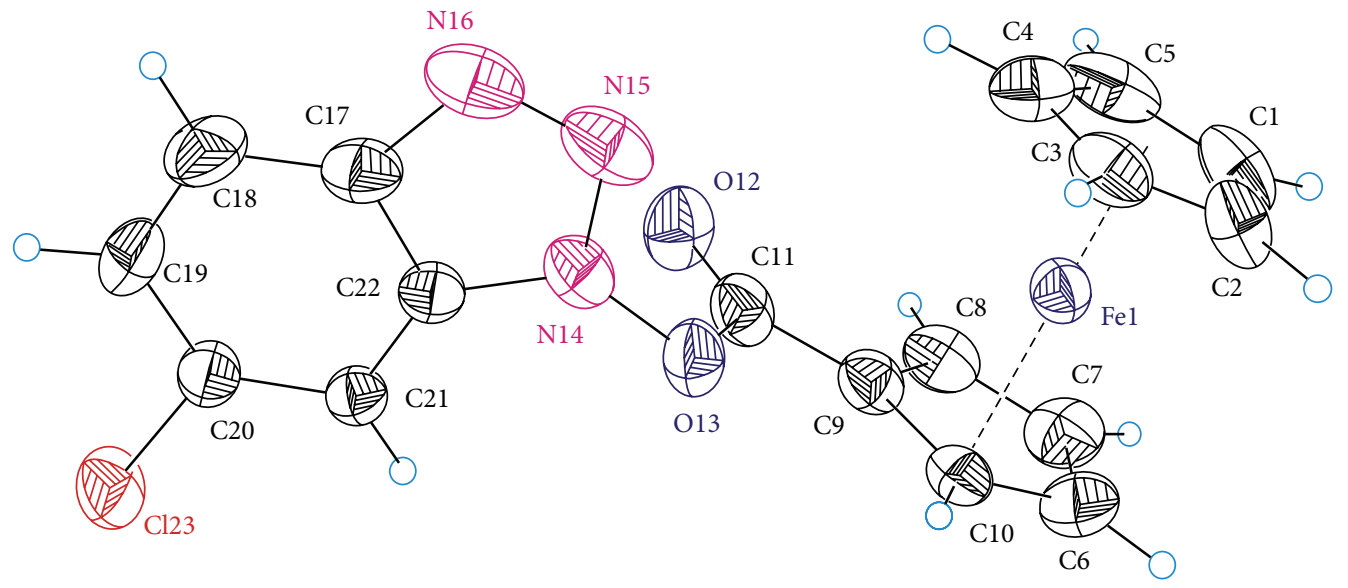

Figure 3: Crystal structure of 2c.

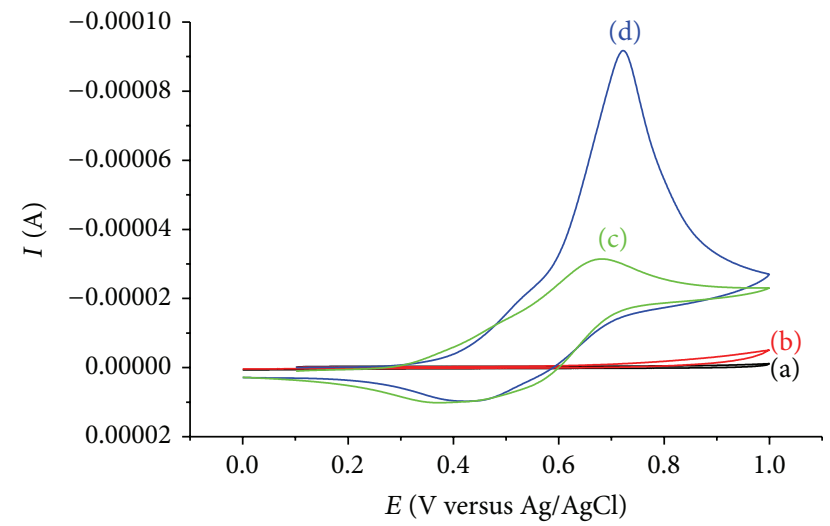

Figure 4: Cyclic voltammograms of (a) nafion modified GCE in $0.1 \mathrm{~mol} \mathrm{~L}^{-1} \mathrm{NaNO}_{3}$; (b) nafion modified GCE in solution of $0.1 \mathrm{~mol} \mathrm{~L}^{-1} \mathrm{NaNO}_{3}$ and $6.0 \times 10^{-3} \mathrm{~mol} \mathrm{~L}^{-1} \mathrm{~L}$-Cys; (c) 2e-nafion modified GCE in $0.1 \mathrm{~mol} \mathrm{~L}^{-1} \mathrm{NaNO}_{3}$ solution; (d) 2e-nafion modified GCE in solution of $0.1 \mathrm{~mol} \mathrm{~L}^{-1} \mathrm{NaNO}_{3}$ and $6.0 \times 10^{-3} \mathrm{~mol} \mathrm{~L}^{-1} \mathrm{~L}-\mathrm{Cys}$.

3.3. Cyclic Voltammetric Behavior of Compounds $2 \boldsymbol{a} \sim 2 \boldsymbol{e}$ and Nafion Modified GCE Electrocatalyze the Oxidation of L-Cys. The preliminarily electrochemical oxidation of L-Cys with the nafion-ferrocene derivatives modified GCE in $0.1 \mathrm{~mol} \mathrm{~L}^{-1}$ different supporting electrolyte solutions, such as $\mathrm{NaCl}$,
$\mathrm{NaNO}_{3}, \mathrm{NaAc}$, and $\mathrm{Na}_{2} \mathrm{SO}_{4}$, has been investigated by cyclic voltammetry. The results (Figure 4) showed that $2 \mathrm{e}$ can promote the electrochemical oxidation of L-Cys dramatically in $0.1 \mathrm{~mol} \mathrm{~L}^{-1} \mathrm{NaNO}_{3}$ solution with a quasireversible process with $\Delta E_{p} \approx 55 \mathrm{mV}$ (curve (d) in Figure 4), while direct oxidation of L-Cys at a GCE is very sluggish (cruve (b) in Figure 4).

\section{Conclusion}

In this study, five ferrocene derivatives (2a $2 \mathbf{2 e})$ were firstly synthesized and structurally characterized using spectroscopic methods. The preliminarily electrochemical oxidation of L-Cys with the nafion-ferrocene derivatives modified GCE in $0.1 \mathrm{~mol} \mathrm{~L}^{-1} \mathrm{NaNO}_{3}$ solution has also been investigated by cyclic voltammetry. The results showed that $2 \mathrm{e}$ can promote the electrochemical oxidation of L-Cys dramatically at its modified GCE with a quasireversible process with $\Delta E_{p} \approx$ $55 \mathrm{mV}$, while L-Cys itself showed a sluggish electrochemical response at GCE. Thus, $2 \mathrm{e}$ modified GCE can be used to detect the trace L-Cys content. (The quantitative analysis of trace L-Cys and electrochemical kinetics of $2 \mathbf{e}$ modified GCE are undergoing.) Based on this research, more ferrocene derivatives will be synthesized and the oxidation of L-Cys and other biological molecules at the modified GCE will be studied soon. 


\section{Conflict of Interests}

The authors declare that there is no conflict of interests regarding the publication of this paper.

\section{Acknowledgments}

This work was financially supported by the 973 Key Program of the MOST (2010CB933501, 2012CB821705), the Chinese Academy of Sciences (KJCX2-YW-319, KJCX2-EW-H01), the National Natural Science Foundation of China and the Natural Science Foundation of Fujian Province (2007HZ0001-1, 2009HZ0005-1, 2009HZ0006-1, and 2006L2005), and Postdoctoral Foundation of Fujian Province.

\section{References}

[1] J. S. Miller and A. J. Epstein, "Organic and organometallic molecular magnetic materials-designer magnets," Angewandte Chemie (International Edition in English), vol. 33, no. 4, pp. 385415, 1994.

[2] P. Nguyen, P. Gómez-Elipe, and L. Manners, "Organometallic polymers with transition metals in the main chain," Chemical Reviews, vol. 99, no. 6, pp. 1515-1548, 1999.

[3] A. Sola, A. Tárraga, and P. Molina, "A ferrocenyl-guanidine derivative as a highly selective electrochemical and colorimetric chemosensor molecule for acetate anions," Dalton Transactions, vol. 41, no. 27, pp. 8401-8409, 2012.

[4] Y. Wang, X. He, K. Wang, X. Ni, J. Su, and Z. Chen, "Ferrocenefunctionalized SWCNT for electrochemical detection of T4 polynucleotide kinase activity," Biosensors and Bioelectronics, vol. 32, no. 1, pp. 213-218, 2012.

[5] L.-Z. Du, J.-F. Gong, C. Xu, Y. Zhu, Y.-J. Wu, and M.-P. Song, "Synthesis and structures of novel diastereomeric cyclopalladated ferrocenylimines derived from chiral $\beta$-amino alcohols," Inorganic Chemistry Communications, vol. 9, no. 4, pp. 410-414, 2006.

[6] J. Zhang, L. Zhao, M. Song, T. C. W. Mak, and Y. Wu, "Highly efficient cyclopalladated ferrocenylimine catalyst for Suzuki cross-coupling reaction of 3-pyridylboronic pinacol ester with aryl halides," Journal of Organometallic Chemistry, vol. 691, no. 6, pp. 1301-1306, 2006.

[7] F. Yang, X. Cui, Y.-N. Li, J. Zhang, G.-R. Ren, and Y. Wu, "Cyclopalladated ferrocenylimines: efficient catalysts for homocoupling and Sonogashira reaction of terminal alkynes," Tetrahedron, vol. 63, no. 9, pp. 1963-1969, 2007.

[8] D. R. van Staveren and N. Metzler-Nolte, "Bioorganometallic chemistry of ferrocene," Chemical Reviews, vol. 104, no. 12, pp. 5931-5985, 2004.

[9] C. Herrmann, P. F. Salas, B. O. Patrick et al., "1,2-disubstituted ferrocenyl carbohydrate chloroquine conjugates as potential antimalarial agents," Dalton Transactions, vol. 41, no. 21, pp. 6431-6442, 2012.

[10] K. N. Tiwari, J.-P. Monserrat, A. Hequet et al., "In vitro inhibitory properties of ferrocene-substituted chalcones and aurones on bacterial and human cell cultures," Dalton Transactions, vol. 41, no. 21, pp. 6451-6457, 2012.

[11] M. M. Abd-Elzaher, S. A. Moustafa, A. A. Labib, H. A. Mousa, M. M. Ali, and A. E. Mahmoud, "Synthesis, characterization and anticancer studies of ferrocenyl complexes containing thiazole moiety," Applied Organometallic Chemistry, vol. 26, no. 5, pp. 230-236, 2012.

[12] K. Kowalski, A. Koceva-Chyła, A. Pieniazek et al., "The synthesis, structure, electrochemistry and in vitro anticancer activity studies of ferrocenyl-thymine conjugates," Journal of Organometallic Chemistry, vol. 700, pp. 58-68, 2012.

[13] L. Soulère and J. Bernard, "Design, solid phase synthesis and evaluation of cationic ferrocenoyl peptide bioconjugates as potential antioxidant enzyme mimics," Bioorganic and Medicinal Chemistry Letters, vol. 19, no. 4, pp. 1173-1176, 2009.

[14] C.-W. Wei, Y. Peng, L. Zhang et al., "Synthesis and evaluation of ferrocenoyl pentapeptide (Fc-KLVFF) as an inhibitor of Alzheimer's A $\beta 1-42$ fibril formation in vitro," Bioorganic and Medicinal Chemistry Letters, vol. 21, no. 19, pp. 5818-5821, 2011.

[15] J. Guillon, S. Moreau, E. Mouray et al., "New ferrocenic pyrrolo[1,2-a]quinoxaline derivatives: synthesis, and in vitro antimalarial activity," Bioorganic and Medicinal Chemistry, vol. 16, no. 20, pp. 9133-9144, 2008.

[16] A. Mahajan, L. Kremer, S. Louw, Y. Guéradel, K. Chibale, and C. Biot, "Synthesis and in vitro antitubercular activity of ferrocenebased hydrazones," Bioorganic and Medicinal Chemistry Letters, vol. 21, no. 10, pp. 2866-2868, 2011.

[17] W. Hao, A. McBride, S. McBride, J. P. Gao, and Z. Y. Wang, "Colorimetric and near-infrared fluorescence turn-on molecular probe for direct and highly selective detection of cysteine in human plasma," Journal of Materials Chemistry, vol. 21, no. 4, pp. 1040-1048, 2011.

[18] X. Guan, B. Hoffman, C. Dwivedi, and D. P. Matthees, "A simultaneous liquid chromatography/mass spectrometric assay of glutathione, cysteine, homocysteine and their disulfides in biological samples," Journal of Pharmaceutical and Biomedical Analysis, vol. 31, no. 2, pp. 251-261, 2003.

[19] N. Sattarahmady and H. Heli, "An electrocatalytic transducer for 1-cysteine detection based on cobalt hexacyanoferrate nanoparticles with a core-shell structure," Analytical Biochemistry, vol. 409, no. 1, pp. 74-80, 2011.

[20] L.-P. Liu, Z.-J. Yin, and Z.-S. Yang, "A l-cysteine sensor based on Pt nanoparticles/poly(o-aminophenol) film on glassy carbon electrode," Bioelectrochemistry, vol. 79, no. 1, pp. 84-89, 2010.

[21] Y.-T. Lai, A. Ganguly, L.-C. Chen, and K.-H. Chen, "Direct voltammetric sensing of 1-Cysteine at pristine $\mathrm{GaN}$ nanowires electrode," Biosensors and Bioelectronics, vol. 26, no. 4, pp. 16881691, 2010.

[22] Y.-P. Hsiao, W.-Y. Su, J.-R. Cheng, and S.-H. Cheng, "Electrochemical determination of cysteine based on conducting polymers/gold nanoparticles hybrid nanocomposites," Electrochimica Acta, vol. 56, no. 20, pp. 6887-6895, 2011.

[23] R. Ojani, J.-B. Raoof, and E. Zarei, "Preparation of poly N,Ndimethylaniline/ferrocyanide film modified carbon paste electrode: application to electrocatalytic oxidation of 1-cysteine," Journal of Electroanalytical Chemistry, vol. 638, no. 2, pp. 241245, 2010.

[24] Z. Liu, H. Zhang, S. Hou, and H. Ma, "Highly sensitive and selective electrochemical detection of L-cysteine using nanoporous gold," Microchimica Acta, vol. 177, no. 3-4, pp. 427433, 2012.

[25] G. Hager and A. G. Brolo, "Adsorption/desorption behaviour of cysteine and cystine in neutral and basic media: electrochemical evidence for differing thiol and disulfide adsorption to a $\mathrm{Au}\left(\begin{array}{lll}1 & 1 & 1\end{array}\right)$ single crystal electrode," Journal of Electroanalytical Chemistry, vol. 550-551, pp. 291-301, 2003. 
[26] Z. Samec, Z. Malysheva, J. Koryta, and J. Pradáč, “A contribution to the voltammetric study of cystine and cysteine at Pt electrodes in $0.5 \mathrm{M} \mathrm{H}_{2} \mathrm{SO}_{4}$," Journal of Electroanalytical Chemistry, vol. 65 , no. 2, pp. 573-586, 1975.

[27] J. Koryta and J. Pradáč, "Electrode processes of the sulfhydryldisulfide system III. cysteine at platinum and gold electrodes," Journal of Electroanalytical Chemistry, vol. 17, no. 1-2, pp. 185$189,1968$.

[28] A. Thakur, S. Sardar, and S. Ghosh, "Click-generated triazole based ferrocene-carbohydrate bioconjugates: a highly selective multisignalling probe for $\mathrm{Cu}(\mathrm{II})$ ions," Journal of Chemical Sciences, vol. 124, no. 6, pp. 1255-1260, 2012.

[29] J. B. Raoof, R. Ojani, and H. Karimi-Maleh, "Electrocatalytic oxidation of glutathione at carbon paste electrode modified with 2,7-bis (ferrocenyl ethyl) fluoren-9-one: application as a voltammetric sensor," Journal of Applied Electrochemistry, vol. 39, no. 8, pp. 1169-1175, 2009.

[30] J. M. Casas-Solvas, E. Ortiz-Salmerón, L. García-Fuentes, and A. Vargas-Berenguel, "Ferrocene-mannose conjugates as electrochemical molecular sensors for concanavalin A lectin," Organic and Biomolecular Chemistry, vol. 6, no. 22, pp. 42304235, 2008.

[31] H. Karimi-Maleh, S. Mehdipour-Ataei, M. Hatami, and M. A. Khalilzadeh, "Voltammetric determination of captopril using a novel ferrocene-based polyamide as a mediator and multi-wall carbon nanotubes as a sensor," Journal of Analytical Chemistry, vol. 69, pp. 162-168, 2014.

[32] W. Guan, X. Duan, and M. A. Reed, "Highly specific and sensitive non-enzymatic determination of uric acid in serum and urine by extended gate field effect transistor sensors," Biosensors and Bioelectronics, vol. 51, pp. 225-231, 2014.

[33] L. Vayssieres, K. Keis, S.-E. Lindquist, and A. Hagfeldt, "Purpose-built anisotropie metal oxide material: 3D highly oriented microrod array of ZnO," Journal of Physical Chemistry B, vol. 105, no. 17, pp. 3350-3352, 2001.

[34] J. Lee, Z. Li, M. Hodgson, J. Metson, A. Asadov, and W. Gao, "Structural, electrical and transparent properties of $\mathrm{ZnO}$ thin films prepared by magnetron sputtering," Current Applied Physics, vol. 4, no. 2-4, pp. 398-401, 2004.

[35] J.-P. Yong and H. A. Aisa, "Chemical modification of rupestonic acid and preliminarily in vitro antiviral activity against influenza A3 and B viruses," Bulletin of the Korean Chemical Society, vol. 32, no. 4, pp. 1293-1297, 2011.

[36] G. M. Sheldrick, SHELXS-97, Program for Solution of Crystal Structures, University of Gottingen, Göttingen, Germany, 1997.

[37] G. M. Sheldrick, SHELXS-97, Program for Refinement of Crystal Structures, University of Gottingen, Göttingen, Germany, 1997. 

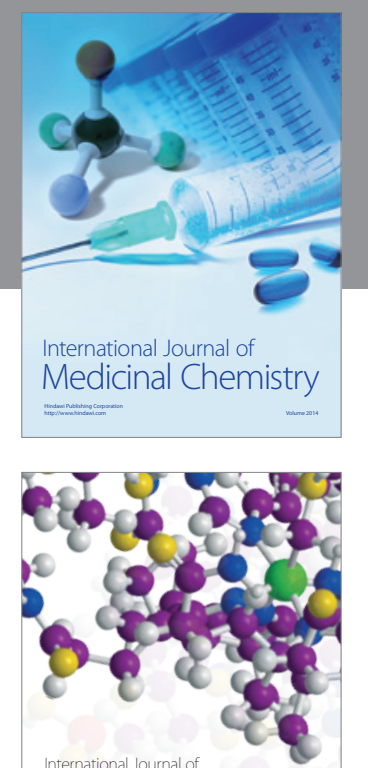

\section{Carbohydrate} Chemistry

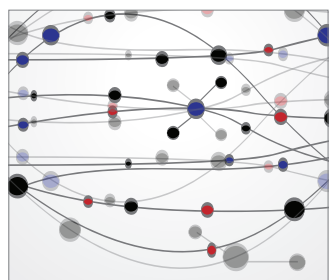

The Scientific World Journal
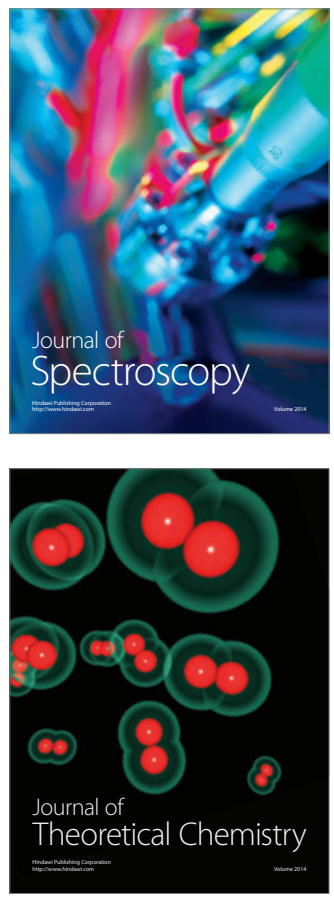
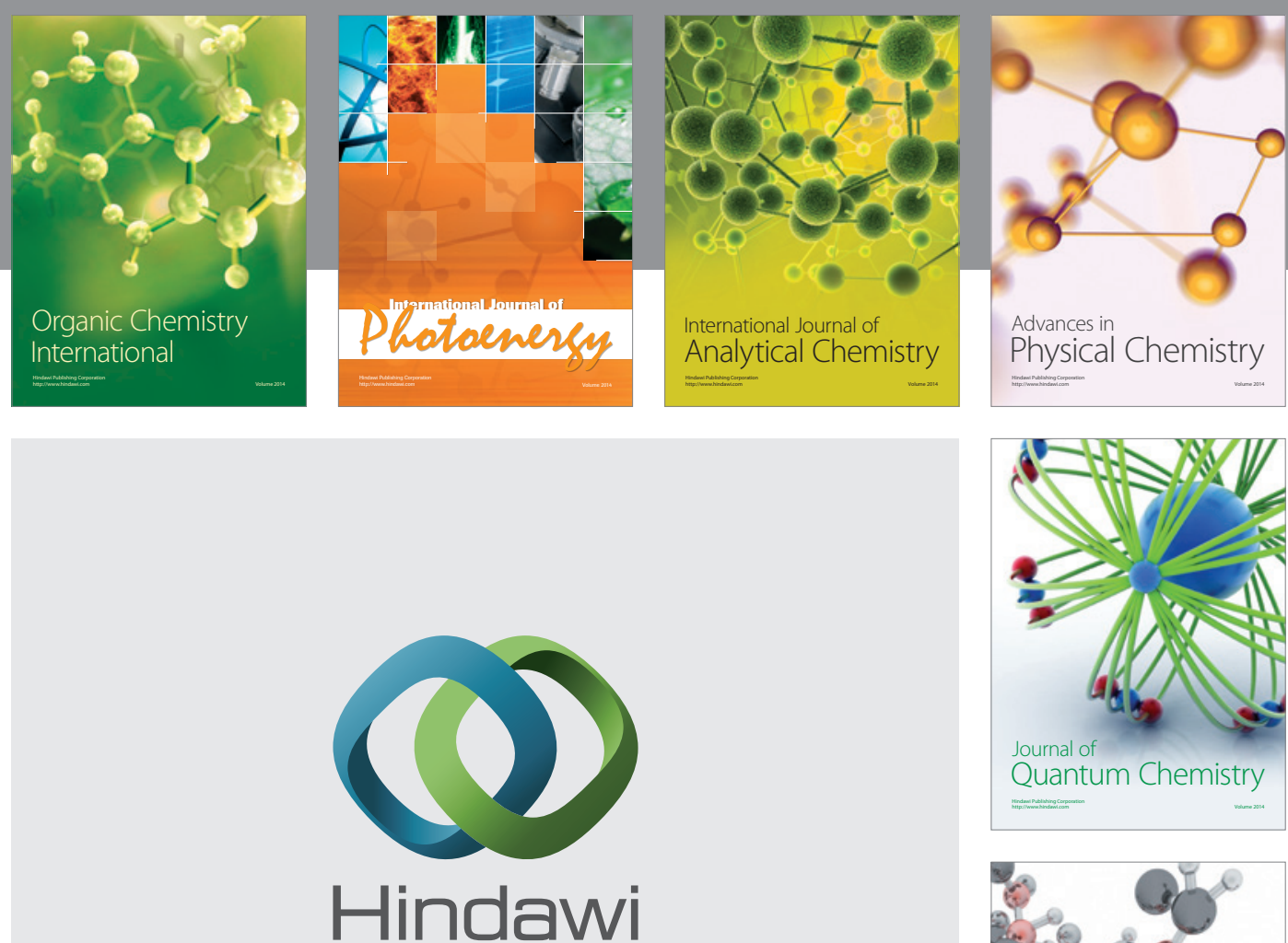

Submit your manuscripts at

http://www.hindawi.com

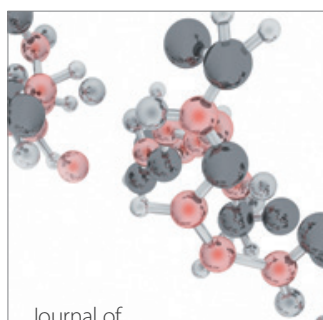

Analytical Methods

in Chemistry

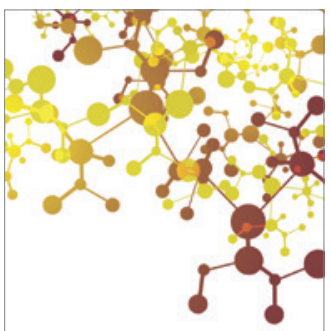

Journal of

Applied Chemistry

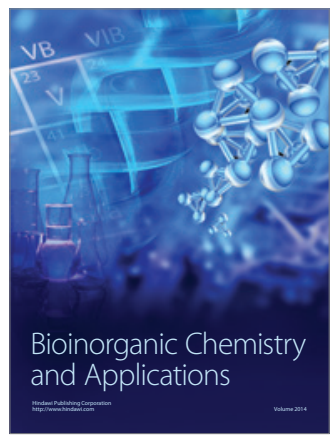

Inorganic Chemistry
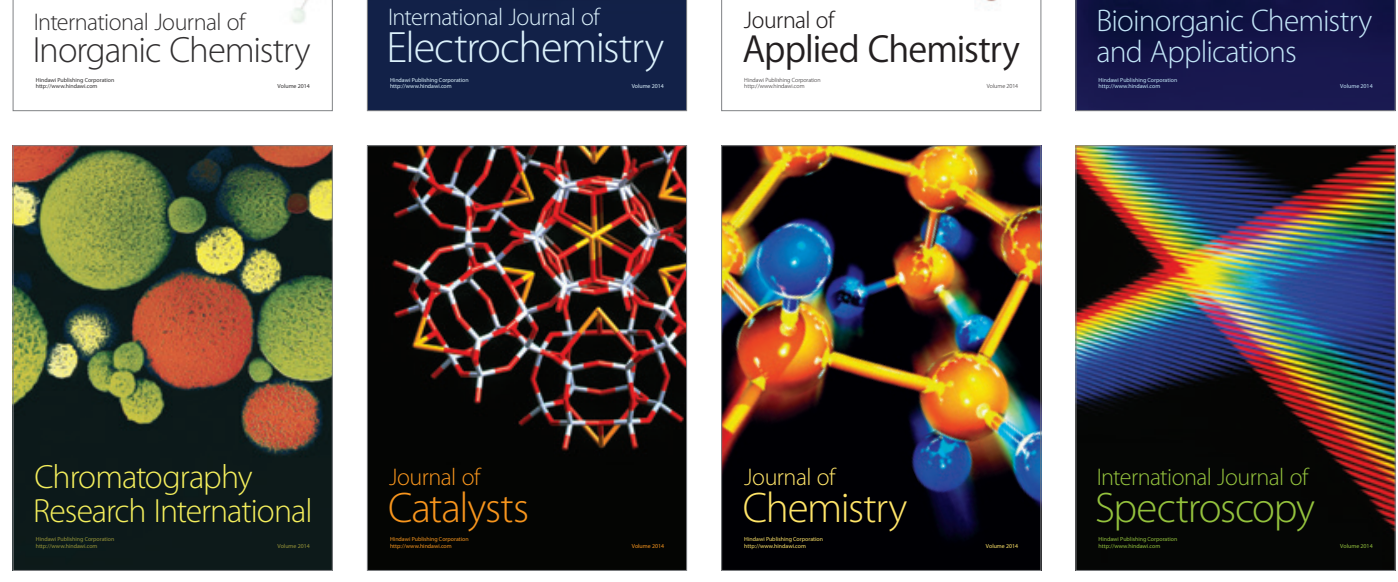